\title{
Pollutant association with suspended solids in stormwater in Tijuana, Mexico
}

\author{
F. T. Wakida $\cdot$ S. Martinez-Huato $\cdot$ \\ E. Garcia-Flores · T. D. J. Piñon-Colin • \\ H. Espinoza-Gomez • A. Ames-López
}

Received: 24 July 2012/Revised: 12 February 2013/Accepted: 23 February 2013/Published online: 16 March 2013

(C) Islamic Azad University (IAU) 2013

\begin{abstract}
Stormwater runoff from urban areas is a major source of many pollutants to water bodies. Suspended solids are one of the main pollutants because of their association with other pollutants. The objective of this study was to evaluate the relationship between suspended solids and other pollutants in stormwater runoff in the city of Tijuana. Seven sites were sampled during seven rain events during the 2009-2010 season and the different particle size fractions were separated by sieving and filtration. The results have shown that the samples have high concentration of total suspended solids, the values of which ranged from 725 to $4,411.6 \mathrm{mg} / \mathrm{L}$. The samples were analyzed for chemical oxygen demand, total phosphorus, total nitrogen, and turbidity. The results show that most of the particles in suspended solids are in the particle fraction between 10 and $62 \mu \mathrm{m}$. A high association between the concentrations of suspended solids was found for chemical oxygen demand, phosphorus, and turbidity but not for total nitrogen.
\end{abstract}

Keywords Chemical oxygen demand · Nitrogen · Nutrients · Phosphate $\cdot$ Pollution · Urban runoff

F. T. Wakida $(\bowtie) \cdot$ S. Martinez-Huato - E. Garcia-Flores .

T. D. J. Piñon-Colin · H. Espinoza-Gomez · A. Ames-López Department of Chemical Sciences and Engineering, Universidad Autonoma de Baja California, Calzada Universidad 14418, Parque Industrial Internacional, Tijuana,

Baja California C.P. 22390, Mexico

e-mail: fwakida@uabc.edu.mx

\section{Introduction}

Stormwater pollution is a major problem in urban areas. The loadings and concentrations of water pollutants, such as suspended solids, nutrients, and heavy metals, are typically higher in urban stormwater runoff than in runoff from rural areas (Vaze and Chiew 2004). Stormwater has become a significant contributor of pollutants to water bodies. These pollutants can be inorganic (e.g. heavy metals and nitrates) and/or organic, such as polycyclic aromatic hydrocarbons and phenols from asphalt pavement degradation (Sansalone and Buchberger 1995). For example, stormwater runoff contributes $75-90 \%$ of the pollution of the Anacostia River, one of the main tributaries in the Chesapeake Bay watershed (NRDC 2002). Factors such as land use and percentage of impervious area (parking lots and roads) can affect stormwater quality. Percentages of impervious areas as low as $10-15 \%$ have been found to degrade the quality of streams (Bochis-Micus and Pitt 2005). Booth and Jackson (1997) analyzed data for streams in west Washington and concluded that developments that had approximately $10 \%$ of impervious area produced degradation in the aquatic life of water bodies. Morse et al. (2003) found that a percent total impervious surface area of $6 \%$ produces an abrupt change in stream insect community structure.

Total suspended solids alone are of the most important parameters measured in stormwater because their concentration and nature are frequently the basis for the selection and design of stormwater treatment facilities, such as retention ponds and wetlands. Moreover, suspended solids are linked to pollutants, such as phosphorus, organic compounds, and some heavy metals, since they tend to be adsorbed in particles (Morquecho and Pitt 2005; Vaze and Chiew 2004). Suspended solids play an important role in 
the transport of anthropogenic nutrients and heavy metals in streams (Horowitz et al. 2008). The concentration of sediment-bound contaminants varies with particle size, with large amounts attached to the finer particles (Taylor and Owens 2009; Brown et al. 2013). Hvitved-Jacobsen et al. (1994) found $60-80 \%$ of phosphorus and lead, $50-60 \%$ of nitrogen, and 30-40\% of zinc in road runoff to be associated with particulates.

Pitt et al. (1998) analyzed 550 samples from telecommunication manholes and vaults that were affected by stormwater. They found that chemical oxygen demand (COD) and zinc concentrations were mostly associated with the filterable fraction (14 and $30 \%$, respectively). Morquecho and Pitt (2005) studied runoff from roofs and paved areas. When suspended solids were removed, they found a reduction of $47 \%$ in the COD, $23 \%$ in total nitrogen (TN), $17 \%$ in nitrate, and $92 \%$ in total phosphorus (TP). For heavy metals, a reduction of $82 \%$ for lead and $72 \%$ for zinc was found. These last results show that lead and zinc concentrations are associated with suspended solids.

Vaze and Chiew (2004) found that the pollutant loads in different particle size ranges from different stormwater samples showed a large variability for $\mathrm{TN}$ and TP. According to these authors, all the particulates TP and TN in stormwater samples are attached to sediments between 11 and $150 \mu \mathrm{m}$. The percentage of the dissolved TN ranged between 20 and $50 \%$ and TP between 20 and $30 \%$.

Mijangos-Montiel et al. (2010) found high concentrations of TSS in stormwater runoff from gas stations and sites with residential land use in Tijuana. TSS concentration ranged from 204 to $11,561 \mathrm{mg} / \mathrm{L}$ for gas stations and 121 to $6,717 \mathrm{mg} / \mathrm{L}$ for residential sites. They also found high concentrations of $\mathrm{COD}$, ranging from 75 to $22,600 \mathrm{mg} / \mathrm{L}$ for gas stations and 60 to $2,135 \mathrm{mg} / \mathrm{L}$ for residential sites.

Domínguez-Chicas et al. (2004) measured the settling velocity of particles in stormwater samples from four sites in Ciudad Juarez, Mexico. They found that the amount of suspended solids and settling velocity of particles are related to urbanization. The amount of suspended solids is reduced and the settling velocity of particles is increased with urbanization. Hansen et al. (2007) found that sediment from urban runoff and wastewater discharge in Cencalli Lagoon in Villahermosa, Mexico was $5,300 \mathrm{~m}^{3} /$ year from an approximate area of 291 ha. They estimated that $80 \%$ of the sediment originated from urban runoff and $20 \%$ from untreated wastewater. The sediment yields from these discharges were calculated by analyzing the land use and population density of the basin.

Little research has been published on urban stormwater runoff quality in Mexico and even less in the Mexican side of the US-Mexico border cities where special urban characteristics that affect the urban stormwater runoff quality exist. These special urban characteristics of Tijuana include: a high percentage of automobiles that circulate in Tijuana are used cars imported from the US; $78 \%$ of the cars in Tijuana are more than 13 years old (INE 2000); and there is unplanned urban land use where a number of unpaved roads can still be found in areas that are considered completely urbanized. In these areas, soil can be transported to paved roads by car tires and then transported by runoff. Another urban feature of Tijuana is the number of vacant lots in the urban area and the steep cut slopes in the hills exposed to erosion, which can contribute suspended solids to stormwater in rain events. According to the municipal planning authority, $22 \%$ of the area in Tijuana comprises vacant lots and approximately $36 \%$ of the total vacant lots have slopes of more than $35 \%$ (Implan 2002).

The aim of this study was to determine the relationship between some pollutants with different particle fractions of suspended solids in stormwater urban runoff in Tijuana, Mexico.

\section{The study area}

The city of Tijuana is located in the northwest corner of Mexico, on the US-Mexico border (Fig. 1). The region has a Mediterranean climate with distinct summer and winter seasons. The average annual rainfall is approximately $230 \mathrm{~mm} /$ year, with over $90 \%$ occurring during the period from November to April (Implan 2002). The rainfall data of the rain events are shown in Table 1 . The rainfall data were collected from Brown Field Airport located $5 \mathrm{~km}$ away from the sampling sites, and by analyzing historical data from another weather station located in the Tijuana area, the approximate rainfall variance across the sampled site area was between 1 and $2 \mathrm{~mm}$.

Four sites have predominantly residential land use, two with industrial land use and one commercial and transport land use. Table 2 shows the sampling sites' characteristics.

Site SR1 has mainly residential land use with a number of street food vendors and businesses. Sites SR2 and SR3 drain an area with houses owned by low-income families. The approximate population density of these two sites is 63 inhabitants/ha and there are a number of auto repair shops. Site SR 4 drains an area of approximately 13 ha with a higher population density (92 inhabitants/ha), populated by high-income families. Sites SI1 and SI2 are located in a zone of industrial land use. The predominant industry in the sampling sites is called "maquiladoras", which are foreign facilities that produce mainly electronic, medical, and plastic products. Site SCT drains an area where three different bus stations are located and commercial land use is predominant. 
Fig. 1 The study area showing the sampling sites

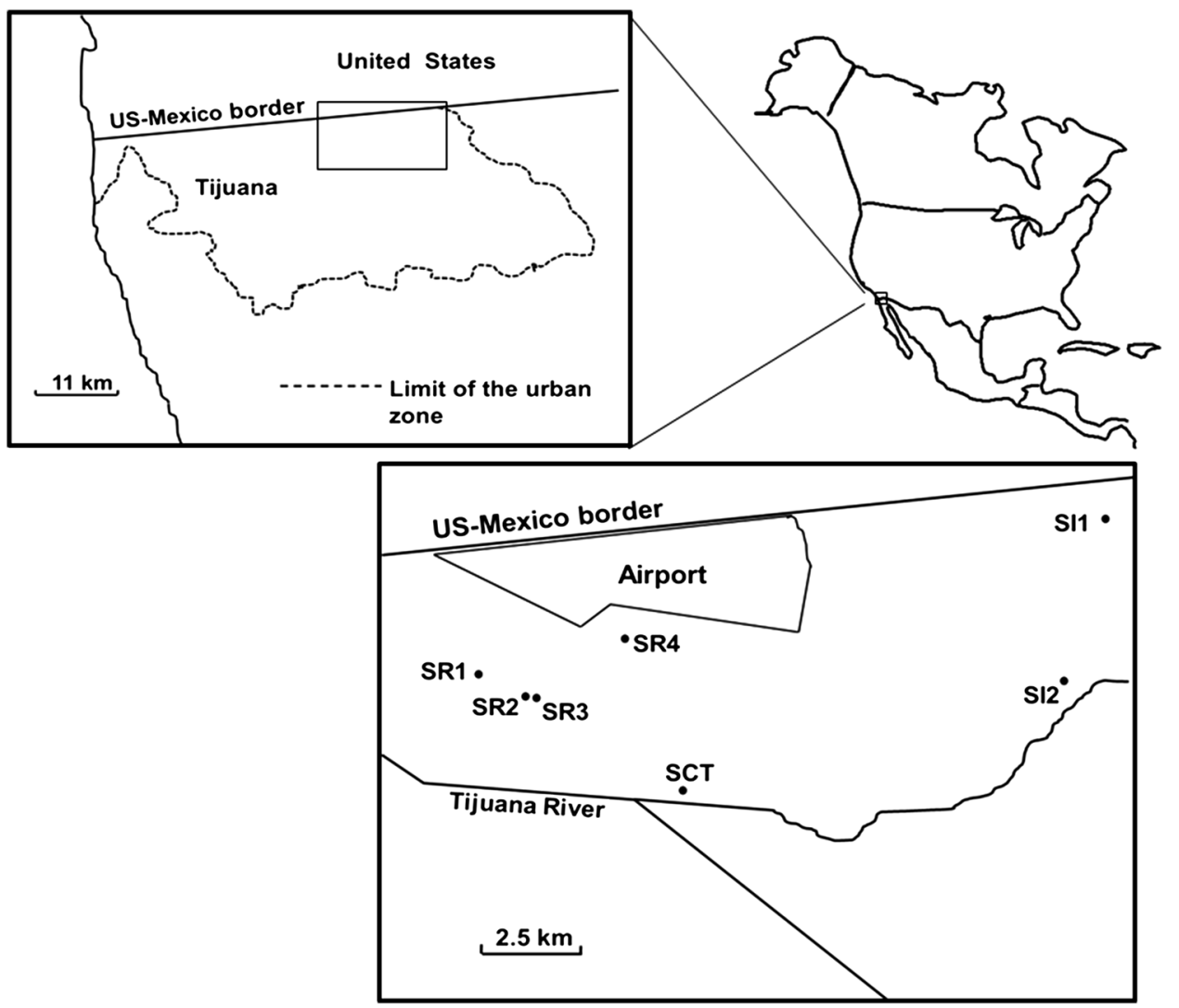

Table 1 Rainfall data of the rain events (modified from GarcíaFlores et al. 2013)

\begin{tabular}{lllll}
\hline $\begin{array}{l}\text { Date } \\
\text { (day-month-year) }\end{array}$ & $\begin{array}{l}\text { Dry days } \\
\text { previous to } \\
\text { rainfall } \\
\text { event (days) }\end{array}$ & $\begin{array}{l}\text { Total } \\
\text { rainfall } \\
(\mathrm{mm})\end{array}$ & $\begin{array}{l}\text { Average } \\
\text { rainfall } \\
\text { intensity } \\
(\mathrm{mm} / \mathrm{h})\end{array}$ & $\begin{array}{l}\text { Maximum } \\
\text { rainfall } \\
\text { intensity } \\
(\mathrm{mm} / \mathrm{h})\end{array}$ \\
\hline $28-11-2009$ & 39 & 10.4 & 1.6 & 4.0 \\
$12-12-2009$ & 13 & 48.8 & 4.5 & 6.0 \\
$18-01-2010$ & 27 & 14.5 & 3.8 & 9.0 \\
$05-02-2010$ & 17 & 6.9 & 2.3 & 4.0 \\
$20-02-2010$ & 14 & 8.9 & 2.2 & 3.0 \\
$27-02-2010$ & 6 & 26.4 & 2.2 & 5.0 \\
$06-03-2010$ & 6 & 2.5 & 1.0 & 1.0 \\
\hline
\end{tabular}

\section{Materials and methods}

The selected sampling sites were located in an area called Mesa de Otay. Seven sites were sampled in seven rain events during the 2009-2010 rainy season. In all of the sites, the samples were taken directly from roads and stormwater drains and inlets. Duplicate samples were taken in each site in the first $2 \mathrm{~h}$ of the rain events. Samples were transported in pre-cleaned, high-density polyethylene containers and were analyzed in the following $24 \mathrm{~h}$.
Table 2 Sampling site characteristics (modified from García-Flores et al. 2013)

\begin{tabular}{llcll}
\hline Site & Land use & $\begin{array}{c}\text { Area } \\
\text { (ha) }\end{array}$ & $\begin{array}{l}\text { \% pervious } \\
\text { area }\end{array}$ & $\begin{array}{l}\text { Average } \\
\% \text { slope }\end{array}$ \\
\hline SR1 & $\begin{array}{c}\text { Residential and } \\
\text { commercial }\end{array}$ & 3.8 & 25 & 12.2 \\
SR2 & Mainly residential & 8.0 & 12 & 4.0 \\
SR3 & Mainly residential & 13.0 & 10 & 3.4 \\
SR4 & Residential & 13.9 & 17 & 3.2 \\
SCT & Commercial & 3.9 & 7 & 1.8 \\
& $\quad$ and transport & & & 0.7 \\
SI1 & Industrial & 3.5 & 9 & 5.1 \\
SI2 & Industrial & 69.1 & 8 & \\
\hline
\end{tabular}

The processing and analysis scheme for each stormwater was conducted as follows: the sample was first split. One split sample was set aside as the unsieved and unfiltered sample. The other was sieved through 300, 150, and $63 \mu \mathrm{m}$ nylon sieves and then filtered using $10,1.2$, and $0.45 \mu \mathrm{m}$ filters.

Each unfiltered/unsieved water sample was analyzed for total suspended solids (TSS), turbidity, total phosphorus as phosphate (TP), chemical oxygen demand (COD), and total nitrogen (TN) using standard methods. The sieved and filtered fractions were also analyzed using the same 
parameters. Total phosphorus analysis was conducted using the method described in Mexican Standard NMXAA-029-SCFI-2001 (SE 2001a); COD was measured using the reactor digestion method described in Mexican Standard NMX-AA-030-SCFI-2001 (SE 2001b); turbidity was measured using the method described in Mexican Standard NMX-AA-038-SCFI-2001 (SE 2001c); TSS was measured using the method described in Mexican Standard NMXAA-034-SCFI-2001 (SE 2001d) and total nitrogen was measured by the persulfate digestion method (D'Elia et al. 1977). Quality control was provided by parallel analysis of spiked samples with certified standards. The percentage of spiked blank recoveries was as follows: $99 \%$ for TP; $92 \%$ for COD, $99 \%$ for TN, and $97 \%$ for TSS. The relative square deviation (RSD) was $0.6 \%$ for $\mathrm{TP}, 1.52 \%$ for COD, $0.4 \%$ for TN, and $2.2 \%$ for TSS. The detection limits in $\mathrm{mg} / \mathrm{L}$ were as follows: 0.133 for $\mathrm{TP}, 1.83$ for COD, 0.4 for TN, and 2.3 for TSS.

\section{Results and discussion}

The cumulative percentages of particle fractions in the samples are shown in Fig. 2. The results have shown that the highest particle fraction mass in the stormwater samples is between 10 and $62 \mu \mathrm{m}$. This particle fraction accounts for between 56 and $82 \%$ of the TSS in the samples. The residential site SR1 has the lowest percentage of particle fractions between 10 and $62 \mu \mathrm{m}$ $(56 \%)$ and the highest percentage of particle fractions between 62 and $150 \mu \mathrm{m}(20 \%)$. This may be due to the high slope of the sampling site resulting in a higher flow velocity of the runoff that can carry bigger soil particles. Another characteristic of this site is the percentage of the basin area that is not paved (bare soil and unpaved streets). This produces higher levels of suspended solids because of the erosion produced by the urban drainage conditions of site SR1.

For the industrial sites (SI1 and SI2), as in all the sites sampled, the highest percentages of suspended solids were in the particle fraction between 10 and $62 \mu \mathrm{m}$. The highest percentage of particle fraction, between 1.2 and $10 \mu \mathrm{m}$, was in site SI1 (approximately $19 \%$ ); this value is more than three times higher than the average value found in the other sites $(5.2 \%)$. The industrial sites also have the highest percentages of impervious area (92 and $91 \%$, respectively). Sites SR1 and SR2 showed the highest percentage of particle fraction in the range from 0.45 to $1.2 \mu \mathrm{m}$ (20 and $8 \%$, respectively), probably due to the high percentage of unpaved surface and the clayey soil.

Table 3 shows the concentration averages and standard deviations for the analyzed parameters. There is a high variability across all the parameters, especially those that are highly associated with solids (TSS, COD, TP, and turbidity). The high variability of stormwater quality is a well-known phenomenon caused by many factors such as: percentage of impervious area and its spatial distribution (roads, parking lots and roofs), type of pervious areas (Goonetilleke et al. 2005), basin soil (Uusitalo et al. 2000), rainfall quantity and quality (Zhang et al. 1999; Hathaway
Fig. 2 Particle size fractions in the stormwater samples

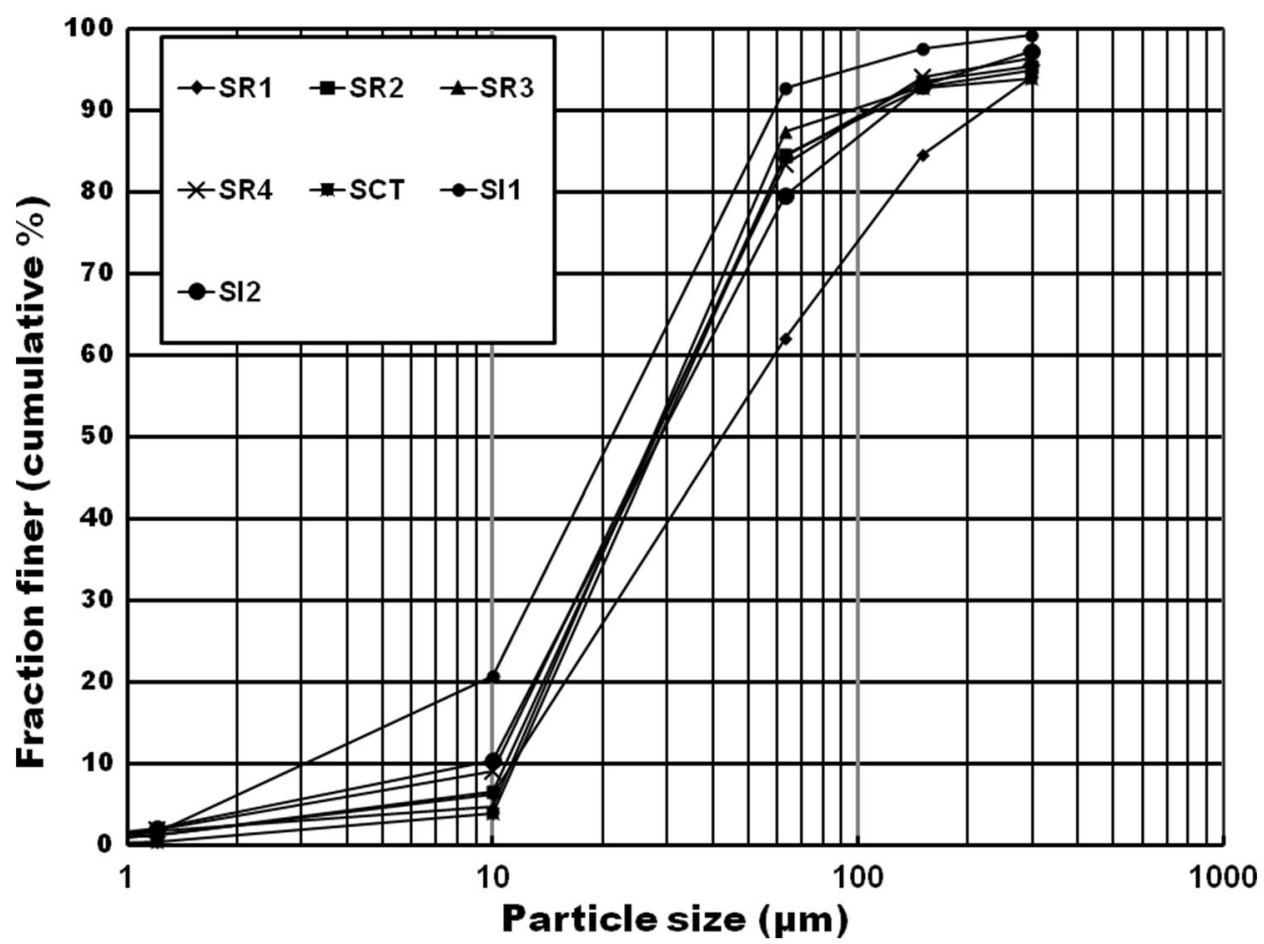


Table 3 Average concentration and standard deviation of measured parameters in unfiltered samples (all data in $\mathrm{mg} / \mathrm{L}$, except turbidity in NTU)

\begin{tabular}{lrlrcc}
\hline Site & \multicolumn{1}{l}{ TSS } & \multicolumn{1}{l}{ COD } & \multicolumn{1}{l}{ TN } & \multicolumn{1}{l}{ TP } & \multicolumn{1}{c}{ Turbidity } \\
\hline SR1 & $4,412 \pm 3,540$ & $765 \pm 382$ & $15.7 \pm 6.3$ & $25.7 \pm 20.9$ & $2,061 \pm 2,406$ \\
SR2 & $1,804 \pm 349$ & $421 \pm 168$ & $9.9 \pm 3.5$ & $17.1 \pm 12.8$ & $1,055 \pm 398$ \\
SR3 & $1,358 \pm 1,086$ & $405 \pm 120$ & $8.4 \pm 1.9$ & $12.0 \pm 6.1$ & $1,497 \pm 1,085$ \\
SR4 & $725 \pm 765$ & $324 \pm 170$ & $13.2 \pm 6.1$ & $7.9 \pm 3.0$ & $454 \pm 320$ \\
SCT & $3,803 \pm 3,417$ & $605 \pm 176$ & $14.1 \pm 6.9$ & $23.4 \pm 10.7$ & $1,975 \pm 1,532$ \\
SI1 & $1,141 \pm 545$ & $218 \pm 78$ & $6.1 \pm 3.4$ & $7.5 \pm 2.8$ & $1,422 \pm 1,093$ \\
SI2 & $2,935 \pm 1,613$ & $362 \pm 228$ & $7.3 \pm 4.6$ & $8.1 \pm 3.6$ & $789 \pm 776$ \\
\hline
\end{tabular}

et al. 2012), and past and present basin activities (Mayer et al. 2002).

The average TSS in the sampling sites ranged from 725 to $4,412 \mathrm{mg} / \mathrm{L}$, the highest TSS concentration observed being in site SR1 (Table 3). The average TSS concentrations are considerably higher than in other published studies (Baldy et al. 1998; He et al. 2010). The average TSS concentration in SR1 and SR4 is 65 and 10 times higher, respectively, than the National Stormwater Data Quality (NSDQ) (Pitt et al. 2004) for a mixed residential land-use site $(68 \mathrm{mg} / \mathrm{L})$. This high TSS concentration in site SR1 is probably due to the high slope and the unpaved streets located in the basin areas of the site that transport high quantities of sediment due to erosion. This site (SR1) also has the highest average concentration of total phosphorus, turbidity, and COD. The TSS concentration in site SR4 $(725 \mathrm{mg} / \mathrm{L})$ was the lowest. This residential site has characteristics that the other sites do not have. First, there is no main road in the basin area. Second, most of the permeable area in the basin consists of a park with grass cover and there are no unpaved streets. Finally, because of the higher socioeconomic level of the residents, the gardens are generally better maintained than in the other residential sites where the patios consisted mostly of bare ground.

The average TP concentrations found in the unfiltered stormwater samples range from 7.5 to $25.7 \mathrm{mg} / \mathrm{L}$. The highest TP concentrations were found in sites SR1 and SCT (25.7 and $23.4 \mathrm{mg} / \mathrm{L}$, respectively). The possible sources of the high TP concentrations in site SR1 may be street dirt and waste from a street market that is set up once a week in the drainage area of the site. For site SCT, the possible source is a small rodeo ring with a stable located just $50 \mathrm{~m}$ away from the sampling site. High TP concentrations were also found in sites SR2 and SR3 (17.1 and $12 \mathrm{mg} / \mathrm{L}$, respectively); the sources may be the same as those mentioned for site SR1. In addition to the sources of TP mentioned above, TP can also originate from soil particles. The highest TP concentrations were found in the sites with a higher percentage of pervious area. Exceptions were sites SR4 and SCT. Site SR4 has a high percentage of pervious area, but phosphorus is not as high as in SR1, SR2 and SR3 because most of its pervious area is a park with no erosion. Interestingly, even though site SCT has a low percentage of pervious area, its runoff presents a high TP concentration. This can be explained by the presence of a stable which acts as a main source point for TP and TN.

The highest average TN concentration was in site SR1 $(15.7 \mathrm{mg} / \mathrm{L})$, the most likely cause being organic debris and street dirt from the number of street food vendors located in the basin of this site. TN concentrations were also high in sites SCT and SR4 (14.1 and $13.2 \mathrm{mg} / \mathrm{L}$, respectively). The source of $\mathrm{TN}$ in site $\mathrm{SCT}$, as mentioned above, is the stable and the rodeo ring where the horses are kept during events. Organic debris may be the main source for site SR4 since this site drains runoff from a park. TN values found in the sampled sites were around three to sevenfold higher than the concentrations reported by Taylor et al. (2005) and the NSQD (Pitt et al. 2004).

The range of COD was from 218 to $765 \mathrm{mg} / \mathrm{L}$, the highest concentration being in site SR1. This may be produced by the high content of TSS in the samples as well as the oil and grease generated by crankcase oil leakages and the street food vendors situated in the drainage area of the site. The average COD values for the other residential sites are between 324 and $421 \mathrm{mg} / \mathrm{L}$, which are approximately 5-8 times higher than the average value reported by the NSQD (Pitt et al. 2004). The high COD values may be the result of crankcase oil leakage from poorly maintained vehicles onto street and parking lot surfaces (MijangosMontiel et al. 2010). García-Flores et al. (2013) found high concentrations of polycyclic aromatic hydrocarbons in the sampled sites: 4,866 $\mu \mathrm{g} / \mathrm{L}$ for site SR4 and 3,483 $\mu \mathrm{g} / \mathrm{L}$ for site SCT. García-Flores et al. (2009) found high concentrations of oil and grease in stormwater samples for the same residential sites (an average of $20 \mathrm{mg} / \mathrm{L}$ ), for the industrial sites $(14 \mathrm{mg} / \mathrm{L})$ and for site SCT $(19 \mathrm{mg} / \mathrm{L})$. These values are five and threefold higher, respectively, than the median values reported for stormwater from residential and industrial land-use sites by the NSDQ (Pitt et al. 2004).

Since turbidity is an indication of the number of particulates in a sample, one would expect higher turbidity values in samples with higher TSS concentration. This was observed for the sampled sites. The highest value of 
Table 4 Percentage of the measured parameters associated with particulate matter

$\% A P$ percentage associated with particulate, $\% F F$ percentage filterable fraction, $S D$ standard deviation

\begin{tabular}{|c|c|c|c|c|c|c|c|c|c|c|c|c|}
\hline \multirow[t]{2}{*}{ Site } & \multicolumn{3}{|l|}{ COD } & \multicolumn{3}{|l|}{$\mathrm{TN}$} & \multicolumn{3}{|l|}{$\mathrm{TP}$} & \multicolumn{3}{|c|}{ Turbidity } \\
\hline & $\% \mathrm{AP}$ & $\% \mathrm{FF}$ & SD & $\% \mathrm{AP}$ & $\% \mathrm{FF}$ & SD & $\% \mathrm{AP}$ & $\% \mathrm{FF}$ & SD & $\% \mathrm{AP}$ & $\% \mathrm{FF}$ & SD \\
\hline SR1 & 79 & 21 & 14 & 59 & 41 & 13 & 93 & 7 & 3 & 99.9 & 0.1 & 0.002 \\
\hline SR2 & 76 & 24 & 9 & 66 & 34 & 18 & 93 & 7 & 6 & 99.8 & 0.2 & 0.001 \\
\hline SR3 & 76 & 24 & 7 & 67 & 33 & 19 & 91 & 9 & 3 & 99.9 & 0.1 & 0.001 \\
\hline SR4 & 75 & 25 & 11 & 49 & 51 & 20 & 82 & 18 & 5 & 99.5 & 0.5 & 0.003 \\
\hline SCT & 82 & 18 & 9 & 60 & 40 & 21 & 92 & 8 & 2 & 99.9 & 0.1 & 0.002 \\
\hline SI1 & 78 & 22 & 13 & 81 & 19 & 25 & 92 & 8 & 4 & 99.9 & 0.1 & 0.016 \\
\hline SI2 & 81 & 19 & 18 & 68 & 32 & 18 & 88 & 12 & 6 & 99.7 & 0.3 & 0.004 \\
\hline
\end{tabular}

turbidity was measured in site SR1 (2,061 NTU) and the lowest value in SR4 (454 NTU). The turbidity value for site SR1 is around 34-fold higher than the values reported by Morquecho (2005).

Table 4 shows the percentage of measured parameters associated with particles in the stormwater samples. The percentage of particle-associated COD varies from 75 to $82 \%$, the highest percentage being in site SCT and the lowest in SR4. The samples from the other sites (SR1, SR2, SR3, SI1, and SI2) show slight variation in the percentage of particle-associated COD (76-81\%). The percentage of particle-associated COD concentrations in this study was higher than the values reported by other studies (Pitt et al. 1998; Morquecho 2005). These authors reported particleassociated COD concentrations from 14 to $63 \%$. This difference in the percentage may be the result of the pollutants adsorbed in the particle surfaces. Crankcase oil stains are commonly seen on streets and parking lot surfaces in Tijuana, where sediment has been deposited. These particles are transported by stormwater and a small amount of the hydrocarbons will be desorbed in water. GarcíaFlores et al. (2009) found that total hydrocarbon concentrations in deposited road sediments were between 1,870 and $7,069 \mathrm{mg} / \mathrm{kg}$.

The percentage values of particle-associated TP were between 82 and $93 \%$, showing a high association with TSS. The lowest percentage of particle-associated TP was observed in site SR4 where pervious surfaces are mostly gardens and a grassy park. The percentage of particleassociated TP was higher than $90 \%$ in most of the samples. These values show, not surprisingly, that most of the phosphorus in the stormwater samples was bound to particles that may originate from eroded soil particles. The percentage of particle-associated TP was also higher than other reported studies. Waschbusch et al. (1999) found $42-79 \%$ of the particle-associated TP in two urban residential basins. The major TP contributor to stormwater in these basins was the runoff from lawns. Runoff from lawns accounted for $55 \%$ of the total TP load from these basins. Morquecho (2005) found a range of 44-64\% of particleassociated TP in stormwater from roofs and paved areas.

The percentage of TN associated with TSS in the stormwater samples was lower than those observed in COD and TP. The percentage values were from 49 to $81 \%$, the majority of the samples being between 59 and $68 \%$. These values are similar to those reported by Vaze and Chiew (2004) which ranged between 50 and $80 \%$ of the total TN associated to particulate. Taylor et al. (2005) reported a lower percentage value for particulate organic nitrogen (24\%) in stormwater.

As expected, the percentage values of turbidity are highly associated with particles and the values are almost $100 \%$. The results show that COD and TP concentrations are highly associated with suspended solids in the samples.

Table 5 Percentage of measured parameters associated with particle sizes higher than 10 and $0.45 \mu \mathrm{m}$

\begin{tabular}{|c|c|c|c|c|c|c|c|c|}
\hline \multirow[t]{2}{*}{ Site } & \multicolumn{2}{|l|}{ COD } & \multicolumn{2}{|l|}{$\mathrm{TN}$} & \multicolumn{2}{|l|}{$\mathrm{TP}$} & \multicolumn{2}{|l|}{ Turbidity } \\
\hline & 10 & 0.45 & 10 & 0.45 & 10 & 0.45 & 10 & 0.45 \\
\hline SR1 & $78 \pm 20$ & $84 \pm 14$ & $53 \pm 11$ & $59 \pm 17$ & $89 \pm 3$ & $93 \pm 3$ & $86 \pm 8$ & $99.9 \pm 0.2$ \\
\hline SR2 & $76 \pm 14$ & $82 \pm 9$ & $49 \pm 21$ & $66 \pm 15$ & $92 \pm 7$ & $93 \pm 6$ & $96 \pm 9$ & $99.8 \pm 0.1$ \\
\hline SR3 & $68 \pm 16$ & $78 \pm 7$ & $31 \pm 22$ & $67 \pm 20$ & $87 \pm 4$ & $91 \pm 3$ & $96 \pm 2$ & $99.9 \pm 0.1$ \\
\hline SR4 & $56 \pm 12$ & $84 \pm 11$ & $51 \pm 13$ & $60 \pm 23$ & $75 \pm 5$ & $82 \pm 4$ & $93 \pm 5$ & $99.5 \pm 0.2$ \\
\hline SCT & $55 \pm 11$ & $85 \pm 9$ & $26 \pm 21$ & $42 \pm 5$ & $89 \pm 2$ & $92 \pm 2$ & $96 \pm 11$ & $99.9 \pm 0.4$ \\
\hline SI1 & $80 \pm 29$ & $86 \pm 13$ & $26 \pm 17$ & $56 \pm 22$ & $87 \pm 5$ & $92 \pm 2$ & $82 \pm 20$ & $99.9 \pm 1.6$ \\
\hline SI2 & $82 \pm 21$ & $94 \pm 17$ & $56 \pm 25$ & $58 \pm 25$ & $80 \pm 15$ & $88 \pm 9$ & $96 \pm 7$ & $99.7 \pm 0.4$ \\
\hline
\end{tabular}


However, no clear association was observed between suspended solids and TN.

Table 5 shows the percentage of the measured parameters associated with particle fraction higher than 10 and $0.45 \mu \mathrm{m}$ in the stormwater samples. Because most of the particle mass in the samples was in the fraction between 62 and $10 \mu \mathrm{m}$, a high percentage of measured parameters was associated with this range of particle fraction. COD percentages of the particle fraction bigger than $10 \mu \mathrm{m}$ vary from 55 to $82 \%$ of the total COD. The particle fraction between 0.45 and $10 \mu \mathrm{m}$ in sites SR4 and SCT was only $5 \%$ of the TSS (Fig. 2), but contributed with 28 and $30 \%$ of the total COD. In the rest of the sites, this particle fraction $(0.45-10 \mu \mathrm{m})$ contributes between 6 and $12 \%$ (Table 5).

The percentages of TN concentration associated with the particle fraction higher than $10 \mu \mathrm{m}$ were between 26 and $56 \%$. The percentages of soluble and particulate TN do not follow a trend, unlike COD and TP. For example, 30 and $36 \%$ of the measured TN in sites SI1 and SR3 are associated with the particle fraction between 0.45 and $10 \mu \mathrm{m}$. Total nitrogen associated with soluble forms of nitrogen in the samples was between 42 and $67 \%$. Total phosphorus measured in the samples was mainly in the particle fraction bigger than $10 \mu \mathrm{m}$, the values ranging from 75 to $92 \%$. The percentage values of particle-associated TP in the range from 0.45 to $10 \mu \mathrm{m}$ were between 1 and $8 \%$.

The results suggest that to effectively remove particulate COD, TP, turbidity, and TN, treatment facilities may have to remove particulate down to $10 \mu \mathrm{m}$. Even so, the facilities may only remove slightly more than half of the TN for sites SR1, SR2, SR4, and SI2 and around a third of the TN for sites SR3, SCT, and SI1 since a large amount of TN is in solution. Due to the biological availability of dissolved nitrogen, its concentration can be reduced by using systems that combine nitrification and subsequent denitrification. Stormwater wetland or biofiltration systems can be appropriate for this role (Taylor et al. 2005).

\section{Conclusion}

The results show that TSS is highly associated with TP, turbidity, and COD. Between 82 and $93 \%$ of the TP and 75 and $82 \%$ of the COD are associated with particles suspended in stormwater. TN concentrations in stormwater samples are not totally linked to particulate since 19-51\% of the TN were dissolved. It is important to know these pollutant:TSS ratios because the selection of a stormwater treatment method must take into account that the removal of this TSS fraction would also eliminate a large proportion of particle-associated pollutants. The results suggest that to effectively remove turbidity, COD, and TP, stormwater treatment facilities must be able to remove particulate down to $10 \mu \mathrm{m}$. Moreover, this facility must be able to combine nitrification and denitrification in order to eliminate nitrogen, since a high percentage of nitrogen is in dissolved form.

Acknowledgments The authors gratefully acknowledge the Universidad Autónoma de Baja California (UABC) for the financial support through its program of research grants (16ta convocatoria de apoyo a proyectos de investigación de la UABC). The authors are also indebted to Professor Samuel G. Meléndez-Lopez for proofreading an earlier version of this manuscript.

\section{References}

Baldy S, Raines TH, Mansfield BL, Sanding JT (1998) Urban stormwater quality, event-mean concentrations and estimates of stormwater pollutant loads, Dallas-Forth Worth area, Texas, 1992-93. USGS Water-Resources Investigations Report, WRIR 98-4158

Bochis-Micus C, Pitt RE (2005) Impervious surfaces in urban watersheds. In: Proceedings of the 78th Annual Water Environment Federation Technical Exposition and Conference, Washington, D.C

Booth DB, Jackson CR (1997) Urbanization of aquatic systems: Degradation thresholds, stormwater detection and the limits of mitigation. J Am Water Resour Assoc 33:1077-1090

Brown JS, Stein ED, Ackerman D, Dorsey JH, Lyon J, Carter PM (2013) Metals and bacteria partitioning to various size particles in Ballona creek storm water runoff. Environ Toxicol Chem 32:320-328

D'Elia CF, Steudler PA, Corwin N (1977) Determination of total nitrogen in aqueous samples using persulfate digestion. Limnol Oceanogr 22:760-764

Domínguez-Chicas A, Kretzschmar T, Núñez-Sánchez F (2004) Sedimentation velocities in pluvial waters of $\mathrm{Cd}$. Juarez, Chihuahua, Mexico. Rev Mex Cienc Geol 21:412-420

García-Flores E, Herrera-Castañon I, Vega-Cruz DA, Lopez-Laureano E, Rodriguez-Ventura G, Espinoza-Gomez H, Wakida FT (2009) Sources of oil and grease in stormwater in Tijuana, Mexico. In: 13th International Conference on Diffuse Pollution and Integrated Watershed Management, 12-15 October 2009. Seoul, Korea, pp 388-390

García-Flores E, Wakida FT, Espinoza-Gomez JH (2013) Sources of polycyclic aromatic hydrocarbons in urban stormwater runoff in Tijuana, Mexico. Int J Environ Res (In press)

Goonetilleke A, Thomas E, Ginn SP, Gilbert D (2005) Understanding the role of land use in urban stormwater quality management. J Environ Manag 74:31-42

Hansen AM, Van Afferden M, Torres-Bejarano F (2007) Remediation of the Cencali lagoon, Villahermosa, Tabasco. I. Pollution and sediment reuse. Ing Hidraul Mex 22:87-102

Hathaway JM, Tucker RS, Spooner JM, Hunt WF (2012) A traditional analysis of the first flush effect for nutrients in stormwater runoff from two small urban catchments. Water Air Soil Pollut 223: 5903-5915

He J, Valeo C, Chu A, Neumman NF (2010) Characterizing physicochemical quality of storm-water runoff from an urban area in Calgary, Alberta. J Environ Eng ASCE 136:1206-1217

Horowitz AJ, Elrick KA, Smith JJ (2008) Monitoring urban impacts on suspended sediment, trace element and nutrient fluxes within the city of Atlanta, Georgia, USA: program design, 
methodological considerations and initial results. Hydrol Process 22:1473-1496

Hvitved-Jacobsen T, Johansen NB, Yousef YA (1994) Treatment systems for urban and highway runoff in Denmark. Sci Total Environ 146/147:499-506

Implan (2002) Programa de Desarrollo Urbano del Centro de Población Tijuana 2002-2025 (Program of urban development of the City of Tijuana). Periódico Oficial del Estado de Baja California, 13 de diciembre de 2002, No. 54

INE (2000) Instituto Nacional de Ecología. Programa de calidad del aire Tijuana-Rosarito 2001-2005 (Program of air quality Tijuana-Rosarito 2001-2005). INE, Mexico. http://www.epa. gov/Border2012/infrastructure/tijuana-airplans/ tijuanarosaritospa.pdf. Accessed 23 October 2009

Mayer B, Boyer EW, Goodale C, Jaworski NA, Van Breemen N, Howarth RW, Seitzinger S, Billen G, Lajtha K, NadelhoffeR K, Van Dam D, Hetling LJ, Nosal M, Paustian K (2002) Sources of nitrate in rivers draining sixteen watersheds in the northeastern US: isotopic constraints. Biogeochemistry 57/58(1):171-197

Mijangos-Montiel JL, Wakida FT, Temores-Peña J (2010) Stormwater quality from gas stations in Tijuana, Mexico. Int $\mathrm{J}$ Environ Res 4:777-784

Morquecho R (2005) Pollutant associations with particulates in stormwater. Dissertation, The University of Alabama. http://rpitt. eng.ua.edu/Publications/Renee.dissertation.pdf. Accessed 14 October 2012

Morquecho R, Pitt R (2005) Pollutant associations with particulates in stormwater. In: Proceeding of the water environment federation, WEFTEC 2005: Session 51 through Session 60, pp 4973-4999 (27). Water Environment Federation

Morse CC, Huryn AD, Cronan C (2003) Impervious surface area as a predictor of the effects of urbanization on stream insect communities in Maine, USA. Environ Monit Assess 89:95-127

Natural Resources Defense Council (NRDC) (2002) Cleaning up the Anacostia River. http://www.nrdc.org/water/pollution/fanacost. asp. Accessed 4 August 2010

Pitt R, Clark S, Lantrip J, Day J (1998) Telecommunication manhole water and sediment study. Special report SR-3841. Vol 2: Water and sediment characteristics

Pitt R, Maestre A, Morquecho R (2004) The National Stormwater Quality Database (NSQD, version 1.1). University of Alabama, Tuscaloosa. http://rpitt.eng.ua.edu/Research/ms4/Paper/MS4\% 20Feb\%2016\%202004\%20paper.pdf. Accessed 20 October 2012

Sansalone JJ, Buchberger GA (1995) Infiltration device as a best management practice for immobilizing heavy metals in urban highway runoff. Water Sci Tech 32:119-125
SE (Secretary of Economy) (2001a) Norma Mexicana NMX-AA-029SFCI-2001. Determinación de fósforo total en aguas naturales, residuales y residuales tratadas (Determination of total phosphorus in natural, wastewaters and wastewaters treated-test method), published in Diario Oficial de la Federación el April 17,2001

SE (Secretary of Economy) (2001b) Norma Mexicana NMX-AA-030SCFI-2001. Determinación de la demanda química de oxígeno en aguas naturales, residuales y residuales tratadas-método de prueba (Determination for chemical oxygen demand in natural, wastewaters and wastewaters treated-test method). published in Diario Oficial de la Federación el April 17, 2001

SE (Secretary of Economy) (2001c) Norma Mexicana NMX-AA-038SCFI-2001. Determinación de turbiedad en aguas naturales, residuales y residuales tratadas-método de prueba (Determination of turbidity in natural, wastewaters and wastewaters treated test method), published in Diario Oficial de la Federación el August 1, 2001

SE (Secretary of Economy) (2001d) Norma Mexicana NMX-AA-034SCFI-2001. Determinación de sólidos y sales disueltas en aguas naturales, residuales y residuales tratadas-método de prueba (Determination of salts and solids dissolved in natural, wastewaters and wastewaters treated-test method), published in Diario Oficial de la Federación el August 1, 2001

Taylor KG, Owens PN (2009) Sediments in urban river basins: a review of sediment-contaminant dynamics in an environmental system conditioned by human activities. J Soils Sediments 9: 281-303

Taylor GD, Fletcher TD, Wong TH, Breen PF, Duncan HP (2005) Nitrogen composition in urban runoff-implications for stormwater management. Water Res 39(10):1982-1989

Uusitalo R, Yli-Halla M, Turtola E (2000) Suspended soil as a source of potentially bioavailable phosphorus in surface runoff waters from clay soils. Water Res 34:2477-2482

Vaze J, Chiew FHS (2004) Nutrient loads associated with different sediment sizes in urban stormwater and surface pollutants. J Environ Eng ASCE 130:391-396

Waschbusch RJ, Selbig WR, Bannerman RT (1999) Sources of phosphorus in stormwater and street dirt from two urban residential basins in Madison, Wisconsin, 1994-95, US Geological Survey Water-Resources Investigation Report 99-4021

Zhang J, Chen SZ, Yu ZG, Wang CS, Wu QM (1999) Factors influencing changes in rainwater composition from urban versus remote regions of the Yellow Sea. J Geophys Res Atmospheres 104(1):1631-1644 